\title{
Pragmatyczne i ideowe aspekty turystyki zrównoważonej
}

\author{
Jakub Mosz \\ Zakład Społeczno Kulturowych Podstaw Turystyki, \\ AWF Warszawa, ul. Marymoncka 34, 00-968 Warszawa \\ kuua@chello.pl
}

\section{Streszczenie}

Turystyka zrównoważona nie jest uznawana za formę turystyki. Kategoria „turystyki zrównoważonej” jest zatem kategorią aksjologiczną. Wyraża pewnien ideał odnoszący się do obrazu społeczeństwa idealnego. Pojęcie „turystyki zrównoważonej" ma status idei uniwersalnej. W modelu turystyki zrównoważonej akcentuje się potrzeby społeczne, ekonomiczne i estetyczne. Nie są one symetrycznie rozłożone między tymi grupami podmiotów. Turystyka zrównoważona traktowana jako model odnoszący się do całej praktyki turystycznej człowieka musi zawierać w sobie przyzwolenie dla ograniczania rozwoju i form turystyki w imię zachowania dóbr wyjątkowych i dla człowieka uniwersalnych. Istotowym dla problematyki turystyki zrównoważonej wydaje sie byc pytanie: Czy turystyka zrównoważona ma dostosować sie do zasad działania obowiązujących we współczesnej cywilizacji czy ma być wzorem działania, który przyniesie zamiany w całej społecznej przestrzeni współczesności? Hasła odnoszące się do sprawiedliwego i równego podziału dochodu z turystyki mają wydźwięk tak społeczny jak i polityczny, odnajdowany w wielu ideologiach rewolucyjnych. Idea turystyki zrównoważonej wskazuje na związek między możliwościami zaspokojenia powszechnej potrzeby podróżowania a konieczności ochrony i zachowania świata, w którym owe podróże się urzeczywistniają. Koncepcja turystyki zrównoważonej wydaje się mieć charakter etosu społecznego akcentującego gatunkową solidarność człowieka biorącego odpowiedzialność za tworzony przez siebie porządek społeczny i otrzymane dziedzictwo kulturowe i przyrodnicze. Istotną kwestią wydaje się być natura owej ortodoksji zrównoważenia.

\section{Slowa kluczowe}

turystyka zrównoważona, podmiot turystyki, aksjologia turystyki, zrównoważenie społeczne

\section{Wstęp}

„Turystyka zrównoważona” zdaje się być niezwykle nośnym pojęciem w obszarze doświadczenia turystycznego. W jej opisach pojawiają się różnorodne określenia wskazujące jej status formalny. Obecne w literturze przedmiotu klasyfikacje turystyki nie należą do struktur jednoznacznie czytelnych. Tworzona przez nie struktura przynależnosci rodzajowej i gatunkowej nie zawsze ma charkter rozdzielny, i nie zawsze doprecyzowuje zmienne leżące u podstaw tych klasyfikacji. W. Gaworecki posługuję sie pojęciem rodzaju turystyki dla pokazania klasyfikacji pierwszoplanowej (Gaworecki 2003). Analogia zaczerpnięta z literaturoznawstwa podsuwałaby tu narzędzie w postaci klasyfikacji rodzajów dla podziału pierwszoplanowego i gatunku dla drugoplanowego. W literaturze przedmiotu turystyki kategoria rodzaju 
zostaje połączona z kategorią formy. Mamy zatem rodzaje turystyki i odpowiadające im formy. Jako główne kryterium wyróżnienia rodzaju turystyki zostaje wskazane kryterium motywacji (Gaworecki 2003:22), którym przypisuje się określone rodzaje turystyki. Punktem odniesienia dla owych motywacji wydaje się być główny z podmiotów praktyki turystycznej - turysta. Pięć pokazanych grup motywacji: fizyczne, psychiczne, interpersonalne, kulturalne i prestiżowe wydaje się być w tym ujęciu strukturą dyskutowalną, z uwagi na ich przedmiotową nierozłączność. Spojrzenie na turystykę z punktu widzenia motywacji podmiotów „kreujących popyt” przynosi odmienną klasyfikację rodzajową. Kolejną klasyfikację przynosi podział turystyki ze względu na „cechę zasadniczą, z punktu widzenia podmiotu turystyki”. Owe cechy to: liczba uczestników, ich wiek, czas pobytu, pora roku, rodzaj zakwaterowania, środek transportu, odziaływanie na bilans płatniczy, rodzaj finansowania, zakres oddziaływania urzędowego, aspekt socjologiczny, sposób zorganizowania podróży, zachowanie się w podróży. Nie dyskutując tutaj zasadności takiego wyrazu przedmiotowego dla „cech zasadniczych z punktu widzenia podmiotu” należy stwierdzić, że uzyskana klasyfikacja rodzajowa nie jest strukturą spójną. Gdy dodamy do tego stosowane w klasyfikacjach kryterium pochodzenia turysty (nie w ujęciu etnicznym) otrzymujemy niezwykły ilościowo i merytorycznie zbiór rodzajów i form turystyki. Konkluzja tej refleksji prowadzi do stwierdzenia, że wśród tego bogatego zbioru form i rodzajów podróżowania nie ma „turystyki zrównoważonej”. Możemy zatem założyć, że turystyka zrównoważona nie jest uznawana za formę turystyki. Uznanie jej za rodzaj turystyki byłoby możliwe gdybyśmy zmienili podstawę przedmiotową kategorii rodzaju i nadali jej znaczenie oceniające, wskazując na status ideowy pojęcia. Innymi słowy każdy z wymienionych w kalasyfikacjach zjawiska turystyki jej rodzaj lub forma może być turystyką zrównoważoną, o ile wypełnia warunki zjawiska zrównoważonego.
Kategoria „turystyki zrównoważonej” jest zatem kategorią aksjologiczną. Wyraża pewnien ideał odnoszący się do obrazu społeczeństwa idealnego, lub raczej cywilizacji idealnej. Czy jest on zawarty w zjawisku turystyki? Analiza definicji zjawiska turystyki pozwala na rozstrzygnięcie dylemtu. Nie wydaje się by stan zrównoważenia można było uznać ze cechę istotową zjawiska turystyki. Zrównoważnie wydaje się być cechą zewnętrzną w stosunku do zjawiska turystyki, odnoszącą się do relacji turystyki z przestrzenią społeczną i przyrodniczą w jakiej mamy z nią do czynienia. Można zatem założyć, że zjawisko turystyki jest rzeczywiste, tak w stanie zrównoważenia jak w stanie niezrównoważenia, przy czym w praktyce turystyki raczej mamy do czynienia z turystyką niezrównoważoną niż zrównoważoną. Turystyka zrównoważona byłaby idealnym modelem praktyki turystycznej uwzględniającym hierarchie wartości, do urzeczywistenienia których dąży cywilizacja zachodu, postrzegana jako cywilizacja będąca w stanie uwzględniać w swojej praktyce perspektywę gatunkową cżłowieka. Nie oznacza to, że cywlizacja zachodu jest cywilizacją zrównoważoną, gdyby tak było praktyka turystyki byłaby postacią turystyki zrównoważonej, ale tylko to, że świadomie tworzy modele idealnego funkcjonowania społeczeństwa. Owe modele pokazują zdolność do postrzegania zagrożeń dla społeczeństwa człowieka i świata, w którym ono sie rozwija i tworzenia procedur umożliwiającyh dokonanie się zmian możliwych w długim horyzoncie czasu. Siła cywilizacji leży w umiejętności dostrzegania zagrożeń i poszukiwania możliwości im przeciwdziałania, jej słabość w tym, że owe modele funkcjonowania pozostają w sferze idei a nie prawa, które by postępowanie zgodne z przesłaniem ideowym wymuszało. Kodyfikacja prawna założeń turystyki zrównoważonej ograniczałaby swobodę gospodarowania i zyski jednego z najważniejszych działów współczesnej gospodarki, jaki stanowi dziś turystyka, mogłaby by też hamować rozwój cywlizacji, takiej jaką znamy i do jakiej jesteśmy 
przyzwyczajeni. Idea turystyki zrównoważonej narodziła się w rozwiniętej cywilizacji poprzemysłowej, która jest świadoma społecznych i przyrodniczych konsekwencji eksploracyjnych zapędów człowieka i gotowa jest brać pod uwagę możliwość uczynienia kroku wstecz, ponieważ idea turystyki zrównoważonej zawiera w sobie ograniczenia działań człowieka, które w konsekwencji prowadzą do zmniejszenia zysków z gospodarki turystycznej. Presja czynnika ekonomicznego pozwala jedynie na formułowanie idei, która mogłaby wskazywać rację dla dobrowolnej rezygnacji z części zysków dla zachowania harmoni struktury cywilizacyjnej człowieka. Społeczności rozwijające się poszukują dróg dojścia do dobrobytu na wszelkie sposoby, dlatego też idea równoważenia rozwoju nie prezentuje dla nich racji akceptowalnych. Z punktu widzenia cywilizacji zachodu idea turystyki zrównoważonej jest krokiem wstecz lub czasem refleksji. Zasadnym wydaje sie zatem pytanie czy możliwym jest tworzenie turystyki od podstaw w modelu zrównoważonym, czy też model turystyki zrównoważonej jest akceptowalny dopiero gdy negatywne skutki rozwoju staną się widoczne tak w przestrzeni społecznej jak i w kondycji świata przyrody. Neoficka presja maksymalizacji zysku wydaje się potwierdzać drugą opcję (Mosz 2012). Argumenty na rzecz zwolnienia rozwoju lub powstrzymania się od przekształcania przestrzeni na nowe potrzeby turystyki nie mają mocy oddziaływania bez wsparcia administracyjnego. Decyzje podejmowane przez mieszkańców lokalności mogą w szybkim tempie prowadzić do nieodwracalnych start, zwłaszcza w obszarze dziedzictwa materialnego człowieka.

\section{Turystyka zrównoważona}

Pojęcie „turystyki zrównoważonej” ma status idei uniwersalnej, rozpowszechnianej przez Światową Organizację Turystyki (WTO) jako „przesłanie” dla wszystkich podmiotów świata turystyki. Jest prezentowane jako nowy etos dla świata turystyki, który powinien być urzeczywistniany w praktyce turystyki całego świata, dotyczyć krajów rozwiniętych i krajów rozwijajacych się. Turystyka zrównoważona ma być obrazem harmonii między hedonistycznymi potrzebami człowieka jako jednostki, relacjami społecznymi podmiotów turystykę tworzących, i światem przyrody, podlegającym, dla potrzeb produktów turystyki, eksploracji ze strony człowieka, zagrażającej dobrostanowi świata przyrody, a w konsekwencji samemu człowiekowi, eksplorującemu przyrodę samym faktem swojego istnienia. Z punktu widzenia praktyki turystycznej wskazuje się dwa obszary, które należy chronić przed zniszczeniem lub nieodwracalnymi zmianami - świat przyrody i lokalne środowisko społeczne człowieka, świat jego kultury, czyli dwa obszary które są przedmiotem eksploracji turystycznej współczesnej cywilizacji. W konceptualizacji „turystyki zrównoważonej" traktuje się praktykę turystyki jako zjawisko w sposób oczywisty akceptowalne przez wszystkich, kwestią fundamentalną nie jest zatem pytanie - Czy uprawiać turystykę? ale - Jak ją uprawiać? Dlatego formułując cel turystyki zrównoważonej nie stawia się kwestii jej zaprzestania, ale „jedynie” kwestię maksymalnego zminimalizowania negatywnego wpływu praktyki turystycznej na świat przyrody i lokalną kulturę człowieka. Świat przyrody zagrożony niezrównoważoną ekspansją człowieka nie jest światem niczyim. Jest częścią jakiejś lokalności, pojawia się zatem kwestia o status własności świata materialnego i swiata przyrody i akceptowalny w wmiarze globalnym zakres ingerencji. Postulaty ekologiczne współczesności wyrażają postawę „współwłasności” ale także współodpowiedzialności. Świat przyrody jest w nich pokazywany jako dobro powszechne a kultura materialna lokalności jako uniwersalne dziedzictwo cżłowieka. Materialna kultura lokalności nie jest zatem postrzegana jako prywatna własność społeczności lokalnych. Takie ujęcie ukazuje też swoistą niesymetryczność postaw, co dobrze widoczne jest w sporze jaki toczy się na Podchalu o swobodę dostępu i eksploracji terenów Tatrzańskiego Parku 
Narodowego. Jest to spór racji ekonomicznych z ideowymi. Turystyka jest świadectwem traktowania kultur loklanych w optyce uniwersalnej jako dóbr, do których dostęp powienien mieć każdy człowiek, zwłaszcza w obrębie jego tożsamości kulturowej i cywilizacyjnej, stąd nieustający rozwój turystyki mający zapokoić potrzeby hedonistyczne i tożsamościowe nowych pokoleń. Historycznie naturalne podziały świata związane z odmiennymi tożsamościami ich fundamentów kulturowych tworzą granice owej uniwersalności, tak jak chociażby w przypadku Mekki, zamkniętej dla przedstawicieli cywilizacji chrześcijańskiej, choć w perspektywie uniwersalistycznej można jej nadać taki sam status jak Wenecji, Barcelonie, Jerozolimie czy Santiago di Compostella. Uniwersalizm gatunkowy nie jest doktryną obowiązującą, stąd też brak symetryczności w postępowaniu przedstawicieli różnych cywlizacji jest cechą charakterystyczną współczesności. Ten brak symetryczności widoczny jest w postrzeganiu dziedzictwa kulturowego. Możliwość zajęcia postawy uniwersalistycznej pozwala na występowanie w obronie dóbr kultury innych cywilizacji, tak jak w przypadku zburzenia 1500 letnich posągów Buddy w Bamjan w Afganistanie, przez afgańskich talibów, a także w przypadku zagrożenia dla świata przyrody jak w przypadku wycinki lasów amazońskich lub wielkiej regulacji rzek w Chinach. Dziewicze środowisko przyrodnicze należy we współczesności do dóbr turystycznych o najwyższym stopniu atrakcyjności, i jak można to pokazać na przykładzie Islandii, zaczyna być eksplorowane turystycznie ponad miarę przez społeczność lokalną i za jej przyzwoleniem przez korporacje turystyczne. Zmiany środowiska przyrodniczego nie są wprost dane tak jak zmiany w przestrzeni antropogenicznej, a impuls jego ochrony pochodzi głównie spoza lokalności, traktującej świat przyrody jako naturalną przestrzeń działalności ekonomicznej. Efekt „kroku wstecz” nie jest zatem dla społeczności lokalnych konceptualizacją ideową, ale realnym działaniem mającym wpływ na jej dobrobyt ekonomiczny. Zrównoważenie cywlizacyjnej praktyki człowieka odnosi sie do wszelkich działań jakie podejmuje człowiek, ale realne staje się tam, gdzie człowiek jako grupa bezpośrednio styka się z naturą i na nią, i na siebie odziałuje, czyli w przestrzeni jego lokalności, w której doświadcza świata w kontekście codzienności. Świadczy to o konieczności zaakceptowania zrównoważonego modelu turystyki na poziomie lokalności. Dziedzictwo lokalności powinno być chronione przede wszystkim właśnie na poziomie lokalności, jak podkreśla J. Urry (Urry 2007). Impulsy dla takiego działania pochodzą głównie z klasy średniej zainteresowanej utrzymaniem tradycyjnej zabudowy architektonicznej będącej zmienną jakości miejsca zamieszkania, co w dalszej perspektywie zawsze skutkuje odczuwalnym dla mieszkańców nasileniem ruchu turystycznego (Urry 2007: 170).

Założeniem turystyki zrównoważonej jest pogodzenie potrzeb ekonomicznych współczesnego społeczeństwa z ograniczeniami świata przyrody, co wydaje się być głównym problemem współczesnej cywilizacji. Z braku harmonii tych dwóch elementów wynikają główne problemy cywilizacyjne takie, jak: ocieplenie klimatu przynoszące kataklizmy pogodowe na całym świecie, ocieplanie mórz, zatrucie wody, zanieczyszczenie powietrza, susza zagrażająca zbiorom żywności, braki naturalnej żywności, braki wody, zagłada gatunków świata przyrody, problemy z wszelkiego rodzaju zanieczyszczeniami, itd. W wmiarze loklanym głównymi problemami staje się stan wód i zanieczyszczenie powietrza. Praktyka i zróżnicowanie turystyki odnoszą się przed wszystkim do zmiennej ilościowej, a postulat turystyki zrównoważonej kierowany jest przede wszystkim do kreatorów turystyki masowej. Jest to obraz pewnego paradosku, albowiem zagrożenie dla środowiska naturalnego i kulturalnego można usunąć, ograniczając ilość turystów bądż rezygnując z pewnych form turystyki lub lokalizacji produktu turystycznego, ale zaspokoić ekonomiczne oczekiwania zróżnicowanych 
grup podmiotów tworzących turystykę można tylko zwiększając ilość turystów. Elitarne, z uwagi na cenę, produkty turystyczne nie rekompensują akceptowalnego równomiernego rozkładu zysku dla wszystkich podmiotów społeczności lokalnej, jaki jest oczekiwany w modelu turystyki zrównoważonej a możliwy w przypadku turysty masowego.

Potrzeby ekonomiczne współczesnego społeczeństwa są enigmatycznym sformułowaniem ukrywającym złożoność relacji społecznych i ekonomicznych wynikających $\mathrm{z}$ istniejącego w świecie turystyki konfliktu interesów podmiotów tworzących zjawisko turystyki. Zjawisko turystyki tworzą trzy grupy podmiotów: twórcy produktu turystycznego, mieszkańcy lokalności w których te produkty są lokowane i turyści. W modelu turystyki zrównoważonej akcentuje się potrzeby społeczne, ekonomiczne i estetyczne. Nie są one symetrycznie rozłożone między tymi grupami podmiotów. Turystów cechują potrzeby estetyczne, $\mathrm{w}$ szerokim rozumieniu tej kategorii uwzględniającym wartości poznawcze. Twórców turystyki motywują głównie potrzeby ekonomiczne, biznes turystyczny jest źródłem zysku. Te same potrzeby wydają się być na pierwszym planie wśród społeczności lokalnych, choć za równie istotne, w planie idealnym, można by uznać potrzeby społeczne związane z oczekiwaniami zmian w funkcjonowaniu przestrzeni lokalności, rozwoju cywilizacyjnego, poprawy standartu życia, tworzeniu miejsc pracy, praktykowania nowych wzorów zachowań. Zjawisko turystyki jest potężnym impulsem ekonomicznym, ale jej wpływ na zmiany społeczne lokalności jest problematyczny. Inwestycje przemysłu turystycznego degradują środowisko naturalne, tworzą enklawy architektoniczne wykorzystywane tylko dla potrzeb turystyki, które w przypadku załamania koninktury lub zawirowań politycznych zostają porzucone i opuszczone, nowe wzory zachowań, które przynoszą turyści niszczą tradycje lokalności nie pozwalając im na trwałe ewolucyjne zmiany, mieszkańcy lokalności nie zawsze są w stanie sprostać oczekiwaniom i wymaganiom pracodawców przemysłu turystycznego otrzymując prace najprostsze, nie gwarantujące stałego zatrudnienia. Biznes turystyczny jaki mogą rozwijać mieszkańcy lokalności w mikroskali zależy od uwarunkowań własności i turystycznej atrakcyjności posiadanej ziemi i zabudowań, nie pokrywającej się z atrakcyjnością funkcjonowania codzienności, co odwraca „przed turystyczną” stratyfikację lokalności, stając sie przyczyną lokalnych sporów i poczucia niesprawiedliwości, wynikającego z niesymetrycznego podziału dóbr jaki przynosi rozwój turystyki (Mosz 2012). Koszty społeczne boomu turystycznego mogą być równie poważne jako szkody jakie ponosi z tego tytułu środowisko przyrodnicze. Moga prowadzić do wymiany lokalności z pierwotnej, historycznej, na nową - turystyczną. Ofiarami takiej zmiany będzie zarówno zabudowa architektoniczna kształtowana na potrzeby turystyczne, zmiana środowiska przyrodniczego, zagłada gatunków, wymiana mieszkańców, ze stałych mieszkańców lokalności na czasowych mieszkańców zaspokajająych potrzeby turystów, zanikanie usług i zawodów, zmiany form gospodarowania, kształtowanie nowych relacji ze światem przyrody, w których przestaje ona być żywicielem spoleczności lokalnej a staje się przestrzenią fizyczną lokowania inwestycji turystycznych. Turystyka stanowi realne zagrożenia dla kultur lokalnych, którym trudno konkurować z atrakcyjnością miejskiego modelu życia, nowych technologii komunikacyjnych, liberalnych wzorów zachowania i sposobów spędzania wolnego czasu, jakie przynoszą ze sobą turyści. Wszelkie nieewolucyjne zmiany wzorów zachowań podatne sa na pochodzące z cywilizacji wielkomiejskiej patologie społeczne, przed którymi trudno się bronić społecznościom nie mającym wzorów dystansu, asertywności, nie mającym świadomości skutków jakie mogą przynosić atrakcyjne dla mieszkańców lokalności wzory zachowań. Procesy zmian społecznych sa naturalną pochodną zmian cywilizacyjnych i turystyka nie jest ani jedynym, 
ani głównym czynnikiem tych zmian. Może być czynnikiem wyzwalającym zmiany lub je ułatwiającym, przyspieszającym. Obraz zmiany społecznej dociera do społeczności lokalnych niezależnie, za pośrednictwem powszechnie dostępnych mediów kultury masowej, które w społecznościach lokalnych postrzegają potencjalnych konsumentów wszelkiego rodzaju dóbr jakie oferuje współczesna cywilizacja, od energii odnawialnych, dronów, kultury eko, wegetarianizmu po wirtualny sex i narkotyki. Wymiana mieszkańców należy również do tendencji cywilizacyjnych współczesności. Migracja do dużych miast, opuszczanie osiedli wiejskich z jednej strony i migracja z miasta na wieś i na tereny atrakcyjne przyrodniczo w poszukiwaniu tradycyjnego modelu życia z drugiej strony. Migracje te nie mają charakteru symetrycznego, więcej ludzi migruje do miast niż z miast, choć z punktu widzenia turystki zrównoważonej jest to zmmiana istotna, gdyż nowe lokalności wiejskie i prowincjonalne kształtują mieszkańcy miast świadomi wyzwań ekologicznych współczesności, sięgający po bizness w turystyce, ale poszukujący spełnienia w microskali co stwarza nadzieję na możliwość urzeczywistniania modelu turystyki zrównoważonej. Owi nowi mieszkańcy mogą wziąć na siebie ciężar odpowiedzialności za rozwój lokalności w modelu zrównoważonym, nie bedąc cywilizacyjnymi neofitami mogą dobrowalnie, w imię wższych wartości rezygnować z działań i technologii przynoszących negatywne skutki dla świata przyrody i społeczności loklanej. Turystyka zrównoważona wymaga działania świadomego, intencjonalnego, potrafiącego przewidywać skutki ludzkich działań dla świata przyrody i struktur społecznych.

\section{Turystyka zrównoważona a obszary chronione}

Odmiennym modelem turystyki zrównoważonej jest turystyka zrównoważona na obszarach chronionych (Mazurkiewicz 2012). W ten sposób określa się zjawisko, które zostaje związane z obszarem już z założenia równoważonym. Jest to bowiem obszar chroniony nie tyle spontanicznymi działaniami człowieka, ale środkami prawnymi wskazującymi działania dozwolone i działania zabronione. Na sześć zdefiniowanych obszarów chronionych turystyka jest dopuszczalna tylko w trzech: w parkach narodowych, miejscach występowania pomników przyrody i parkach krajobrazowych (Mazurkiewicz 2012: 158). Przyzwolenie na praktykę turystyczną w tych miejscach nie ma jednak charakteru otwartego, dowolnego, ale jest ściśle regulowane. Zakres owych regulacji może być dyskutowany między grupami interesu tworzącymi świat turystyki, prowadząc do otwierania lub zamykania tych obszarów dla turystyki. Zrównoważenie ruchu turystycznego w przestrzeni chronionej nie ma charakteru postulatu ideowego, ale jest wyrazem funkcjonujących regulacji prawnych stanowiących naczelną zasadę działania dla podmiotów turystycznych. Należy podkreślić, że ten kontekst zrównoważenia ma na względzie pierwszoplanowy charakter zagrożeń dla świata przyrody, którym wszelkie inne potrzeby pokazywane w praktyce turystycznej zostają podporządkowane. W tym kontekście zarysowuje się płaszczyzna konfliktu interesów między podmiotami turystyki. Ponieważ świat przyrody nie jest podmiotem doświadczenia turystycznego, w jego imieniu występują grupy podmiotów, tak społeczności lokalnych jak i cywilizacji globalnej, chroniąc podstawowy interes świata przyrody jakim jest jego przetrwanie. Obszar chroniony zawiera dobra świata przyrody o pożądanych przez turystów walorach estetycznych. $Z$ definicji są obszarami unikatowymi, stanowią zatem atrakcję i naturalny przedmiot pożądania ze strony turystów. Są nim zatem zainteresowani tak sami turyści jak twórcy produktów turystycznych. Udostępnianie owych dóbr narażone jest zatem na występowanie presji ekonomicznego zysku z intensyfikacji ruchu turystycznego, także ze strony zarządzających obszarami chronionymi, są one bowiem zwykle niedofinasowane w stosunku do potrzeb. Zagrożenia mogą zatem 
pochodzić od działań mających na celu zapobieganiu zagrożeniom dla środowiska naturalnego. Stosowanie modelu turystki zrównoważonej na obszarach chronionych musi kierować się racjami racjonalnymi. Zachowanie przyrody dla niej samej nie wydaje się dla wspólczesnej cywilizacji racją wystarczającą. Człowiek kieruje się raczej przyjemnością jaką może wywoływać obcowanie z przyrodą. Owa przyjemność jest doznaniem o złożonej strukturze. Składają sie na nią doznania estetyczne, jakich dostarczają odnajdywane w przyrodzie wartości piękna i dramatyczności, doznania zmysłowe, które tworzą smaki, zapachy, dźwięki, przyjemności ciała zmagającego się ze światem natury, kontakty ze światem zwierząt, do jakich należą obserowanie zwierząt, opieka nad zwierzętami, ale także polownie na zwierzęta i ich zabijanie. Człowiek niezmiennie żywi przekonanie, że świat przyrody jest strukturą odtwarzalną i samoregenerującą się, co skłania go do jego nadmiernej eksploracji, zapominając, że zdolności regeneracji środowiska przyrodniczego zakładają ustanie procesu jego degradacji, przynajmniej na czas jego odtwarzania. W rozważanym przez nas kontekście oznaczałoby to usunięcie ze świata przyrody człowieka i pozostawienie jej samej sobie, co nie wydaje się być akceptowalne. Współczesny człowiek źle przyjmuje ograniczenia swojej wolności i swobody działania, traktując świat przyrody przedmiotowo, przyzwyczajony do wywyższania jedenj formy życia nad drugą. Turystyka zrównoważona na obszarach chronionych zmienia swoją postać - przestaje być ideą, postulatem, jest bowiem możliwa w ramach regulacji prawnych chroniących świat przyrody obszaru chronionego - jej rozwój jest możliwy w ramach prawa, a rozważania na temat turystyki zrównoważonej na obszrazch chronionych przyjmują postać poszukiwania rozwiązań technicznych dla tworzenia i rozwoju turystyki w ramach ograniczeń jakie narzuca prawo chroniące obszary świata przyrody zagrożone zniszczeniem. Społeczności lokalne nie podlegają takiej prawnej ochronie jak świat przyrody, mimo że wiele z nich powinno mieć status obszarów chronionych.

Tak jak dobra przyrody uważa się za odtwarzalne tak dobrom kultury nadaje sie status niepowtarzalności. Dzieła sztuki stanowiące jeden z ważniejszych atrybutów atrakcyjności turystycznej traktuje się jako wyjątkowe, unikatowe, jedyne, niepowtarzalne, stad też miejsca w których są ulokowane są naturalnymi "mekkami” turystyki. Świadomość zagrożeń na jakie narażony jest świat sztuki jest współcześnie bardzo wysoka. Wspłóczesna cywilizacja obeserwuje takie procesy w przypadku architektury, rzeźby, malarstwa i świadomie im zapobiega, sięgając po narzędzie zrównoważonego dostępu. Zrównoważona turystyka dóbr kultury to przede wszystkim ograniczanie dostępu, a w skrajnych przypadkach zamykanie miejsc i obiektów narażonych na zniszczenie i bezpowrotną utratę. Dzieła sztuki chroni się przed człowiekiem z powodu kradzieży, aktów wandalizmu i zniszczeniem, jakiego może dokonać człowiek dotykając powierzchni, wydychając szkodliwe substancje, emanując ciepło, lub wystawiając dzieła sztuki na działanie skażonego powietrza, którym wszyscy dziś oddychamy. Dla wielu dzieł sztuki zagrożeniem jest współczesna cywilizacja. Szansą dla ich przetrwania może być ich całkowita od niej izolacja, tak jak w przypadku Pompejów. Dostęp do wielu dzieł sztuki jest zatem zakazywany, tak jak w przypadku Lascaux, bądź ściśle reglamentowany tak jak w przypadku Altamiry. Niektóre z dóbr kultury prezentuje się tylko okazjonalnie. Dla utrzymania zainteresowania turystów tworzy się repliki obiektów, tak jak w przypadku fresków z groty w Altamirze. W przypadku dóbr kultury zasady turystyki zrównoważonej wydają się spotykać z całkowitą akceptacją, choć rezygnacja z możliwości doświadczenia pewnych jakości estetycznych nie przychodzi współczesnemu człowiekowi z łatwością. Wirtualna dostępność wszelkich obiektów kulturowych może być namiastką rzeczywistego z nimi obcowania, ale nie pozostaje ona w harmonii z założeniami 
praktyki turystycznej, „tradycyjnie” zakładającej doświadczanie rzeczy w świecie materialnie rzeczywistym. Możemu uzanć, że każdy człowiek ma prawo obcować ze sztuką i pięknem w ich najwspanialszych urzeczywistnieniach. Jest to bardzo mocna racja za utrzymaniem praktyki turystycznej. Temu między innymi ma służyć turystyka. Jest to chyba jedyna racja akceptująca obecność innych w przestrzeniach zagrożonych zniszczeniem. Nie wydaje się by racjonalną i uzsadnioną mogła być argumentacja na rzecz pomnażania czyjegokolwiek zysku. Umożliwienie człowiekowi doświadczania rzeczy pieknych jest jedyną dopuszczalną argumentacją za kontynuowaniem praktyki turystycznej w przestrzeniach zagrożonych, ale tylko na warunkach jakie gwarantują przetrwanie owych dóbr i społeczności. Kompromis w tym kontekście jest akceptowalny tylko w jednym wymiarze jako przyzwolenie na obecność turystów, ale jedynie $\mathrm{w}$ formie i ilościach wyznaczanych zachowaniem interesu dóbr chronionych. W sytuacji zagrożenia owych dóbr ruch turystyczny mógłby być całkowicie zakazany, co należy do akceptowanej społecznie praktyki ścisłych rezerwatów przyrody, mimo ich niezwykłej atrakcyjności. Ponieważ praktycznie kompromis taki dotyczyłby tylko jednej strony, nie byłby rzeczywistym kompromisem wymagającym zysku i straty każdej ze stron (Mazurkiewicz 2012). Każdy człowiek oznacza prawie 7,5 mld osób. Wystraczy, żeby tylko proprocjonalnie, tak jak to jest w przypadku Polski, tylko 6\% mieszkańców Chin i Indii chciało odwiedzić Europę, co jest do pomyślenia z uwagi na cywlizacyjny rozwój tych regionów, to w Wenecji przybyłoby w jednym sezonie ok 150 mln turystów, co mogłoby oznaczać, że trzeba by rezerwować z wielomiesięczym wyprzedzeniem kolejkę na wjazd lub losować pozwolenia na wjazd, zachowując stale ograniczoną, akceptowalną dla tego miejsca ilość turystów. Jeżeli przyjmiemy, że muzeum Luwru odwiedza rocznie $9 \mathrm{mln}$ zwiedzająych, to czas jego zwiedzania turystów tylko dla tej grupy turystów rozciągałby się na 16 lat. Praktyka losowania wstępu do atrakcji turystycznej jest już stosowana w Altamirze, raz w tygodniu 5 osób może wygrać los na zwiedzanie prowdziwej jaskini, jest to zatem jeden $\mathrm{z}$ dopuszczalnych modeli równoważenia ruchu turystycznego. Ze społecznego punktu widzenia jest to praktyka tworzenia nierówności społecznych, choć forma losowania ma teoretycznie charakter egalitarny. Model społeczeństwa egalitarnego w wymiarze absolutnym jest raczej konstrukcja teoretyczną, przy współczesnym, permanentnym wzroście populacji, i należy zaakceptować swoistą elitarność potrzeb, nie wszyscy będą mogli doświadczać tego czego by chcieli, ale też nie wszyscy chcą doświadczać tego samego. Takie rzeczywiste zróżnicowanie potrzeb pozwala na wprowadzanie w życie modelu turystyki zrównoważonej. Społeczny mechnizm naśladowania wzorów zachowań innych może być zagrożeniem dla elitaryzmu idei zrównoważenia praktyki turystycznej, ale praktyka realnego uczestnictwa w kulturze wyższej pozwala na tworzenie takiego modelu. Mona Lisa pozostanie pewnie pozycją obowiązkową, aczkolwiek festiwal Wagnerowski pozostanie raczej atrakcją elitarną, pozostawiając pole egalitarnemu Disneylandowi. Dotyczy to także obcowania z naturą. Jedna z najciekawszych tego rodzaju praktyk, jaką jest „bird watching”, cieszy się umiarkowaną popularnością, pozwalającą na praktykowanie jej w modelu zrównoważonym.

Paradoks turystyki polega na tym, że człowiek praktykujący turystykę niszczy to co jest dla niego najbardziej atrakcyjne, to co jest wyjątkowe, uniklane, niepowtarzalne. Nie jest to jednak działanie intencjonalne. Jest to prosta konsekwencja zmiennej ilościowej, która zaczyna stanowić zagrożenie dla cywilizacji człowieka. Konsumpcyjny wzór zachowania charakteryzujący współczesną cywilizację jest naśladowany we wszystkich społecznościach. Dotyczy to także turystyki, która oferuje produkty egalitarne w wyniku umasowienia praktyki turystycznej. Wszystko to co sprzyja rozwojowi turystyki zachęca do jej maksymalizacji. W świecie podróżujących milionów 
turystów trudno jest zbudować i zachować aurę wyjątkowści. Elitarność współczesnych praktyk turystycznych wyraża się w poszukiwaniu wyjątkowości, której nie skonsumują wszyscy. Powszechne potrzeby tworzenia wizerunku na portalach społecznościowych sprawiają, że dzielimy się z innymi odkrywaną przez nas wyjątkowością miejsc i rzeczy, co jest aktem jej upowszechnienia. Im więcej osób obserwuje nasz profil tym bardziej zagrożone na umasowienie są miejsca, które odkrywamy i obdarzamy wyjątkowością, tym wiecej osób chce móc doświadczać tego czego my doświadczamy. Pragniemy upowszechniać wyjątkowość odbierając jej tym samym ów status szczególny. Zrównoważenie turystyki elitarnej wydaje się być naturalne i wpisane niejako w jej istotę. Zachodni indywidualizm może rzecz jasna kierując się hedonistycznymi potrzebami podmiotów przyczyniać się do degradacji środowiska w równym stopniu co turystyka masowa lub wyłączać je z egalitarnej przestrzeni turystycznej poprzez akty zawłaszczania dóbr kultury i świata przyrody na swoje potrzeby. Idea turystyki zrównoważonej zawierająca w sobie przesłanie ograniczania się, dobrowolnej rezygnacji z imperatywu zaspokajania potrzeb nieegzystencjalnych i praktyk je realizujących, jest ideą bliższą cywilizacjom wschodu niz zachodu, z uwagi na istotową dla kultury wschodu postawę kolektywistyczną. Dobro wspólne jest w kulturach dalekiego wschodu wartością realną, leżącą u podstaw cywilizacji. Powoływanie się na interes przyszłych pokoleń jest wskazaniem na potrzebę przechowania świata kultury i natury we wspólnym interesie trwania cywilizacji.

Turystyka zrównoważona traktowana jako model odnoszący się do całej praktyki turystycznej człowieka musi zawierać w sobie przyzwolenie dla ograniczania rozwoju i form turystyki w imię zachowania dóbr wyjątkowych i dla człowieka uniwersalnych. Najmniej wyraziste wydają się być w tym kontekście społeczności lokalane, mające z perspektywy turystki bardziej charakter powszechny niż uniwersalny i raczej ujmowane jako różnorodne niż wyjątkowe. W przeciwieństwie do dóbr kultury i świata przyrody społeczności lokalne mają charakter podmiotowy, zwłaszcza w społeczeństwach demokratycznych i mają możliwość decydowania o swoim fnkcjonowaniu. Mogą kształtować turystykę zgodnie ze swoimi potrzebami i potrzebami środowiska swojej loklaności (Urry 2007).

Cywilizacja Zachodu, w której pojawia się idea zrównoważonej turystyki jest sama w sobie cywilizacją niezrównoważoną, zagrażającą samej sobie poprzez naruszanie struktur świata przyrody. Hasła zrównoważenia ludzkiej cywilizacji są hasłami głoszonymi przez ruchy ekologiczne, nie mające realnej siły politycznej i prawnych narzędzi oddziaływania. Symetria widoczna jest w budowaniu przekazu ideowego odwołującego się do obrazu zagłady cywilizacji naruszającej porządek świata natury. Brak społecznego poparcia dla ruchów ekologicznych, wyrażający się między innymi niskim procentem głosów w wyborach partii opierających swoją tożsamość polityczną na przesłaniu ekologii wynika zapewne z trudnej do zaakceptowania postawy wyrzeczenia się części wolności w imię abstrakcyjnego dobrostanu przyszłości. Naturalnym zatem stają się pytania - Czy możliwa jest turystyka zrównoważona w przestrzeni cywilizacji niezrównoważonej? Czy możliwe jest zrównoważenie jednego z elementów struktury przy jednoczesnym pozostawieniu niezrównoważenia jej całości? Czy turystyka zrównoważona ma dostosować sie do zasad działania obowiązujących we współczesnej cywilizacji czy ma być wzorem działania, który przyniesie zamiany w całej społecznej przestrzeni współczesności? Jej hasła odnoszące się do sprawiedliwego i równego podziału dochodu z turystyki mają wydźwięk tak społeczny jak i polityczny, odnajdowany w wielu ideologiach rewolucyjnych. Są wskazaniem na wartości społeczeństwa obywatelskiego, dyskutującego swój rozwój na poziomie lokalności. Odwołują się także do powszechnie uznawanych i pożądanych dóbr jakie oferuje 
praktyka turystyki, co może być dobrą racją dla zaakceptowania nowego wzoru zachowania - racjonalnej eksploracji połączonej $\mathrm{z}$ gotowością do wyrzeczenia się, w imię zachowania dóbr świata natury i kultury, którymi dysponuje człowiek. Idea turystyki zrównoważonej wskazuje na związek między możliwościami zaspokojenia powszechnej potrzeby podróżowania a konieczności ochrony i zachowania świata, w którym owe podróże się urzeczywistniają. Ta idea może wpłynąć na postępowanie człowieka i wymusić zamiany cywilizacyjne. Ofiarą braku zrówoważenia cywilizacji człowieka stanie się w ostatecznym rozrachunku sam człowiek. Człowiekowi niezmiennie brakuje gatunkowej perspektywy dla spojrzenia na świat natury, stanowiący podstwę jego egzystencji. Zakodowanie ideei społecznych w przesłaniu turystyki zrównoważonej ma potencjalną szansę realnego oddziaływania na człowieka, bowiem jak zauważa D. MacCannell wszyscy jesteśmy turystami, chcemy być turystami, chcemy by nasze dzieci mogłyby być turystami (MacCannell 2002). Podróżowanie należy do najbardziej cenionych przez człowieka dóbr jako źródło przyjemności i możliwość manifestowania wolności. Jest ważnym elementem stylu życia i wyznaczania społecznej pozycji. Można założyć, że dla zachowania tych wartości człowiek skłonny będzie urzeczywistnić idee turystki zrównoważonej, a nawet rozważać kwestię równoważenia rozwoju swojej cywilizacji kształtując nowy ład społeczny. Urzeczywistnianie praktyki turystycznej w modelu turystyki zrównoważonej będzie wymuszało rezygnację z określonych działań wobec środowiska przyrodniczego i społeczności loklanych. Zjawisko turystyki jest zjawiskiem odzwierciedlającym życie społeczne w jego całości i jako takie stanowi część życia społecznego i gospodarczego. Nie ma możliwości zmiany jednej praktyki, jeżeli jest ona strukturalnie powiązana $\mathrm{z}$ całością i mechanizmami jej funkcjonowania. Realizowana w praktyce idea zrównoważenia może wymuszać na społecznościach lokalnych rezygnację z planów zagospodarowania turystycznego przestrzeni lokalności, co z kolei pozostaje w sprzeczności z treściami społecznymi odnoszącymi się do równomiernego podziału dóbr i tworzenia warunków rozwoju dla społeczności lokalnych. Niektóre społeczności lokalne mogą sprzeciwiać się praktyce turystyki zrównoważonej pomimo tego, że będzie ona chroniła ich środowisko naturalne, antropogeniczne i samą społeczność pozwalając jej przetrwać w nienaruszonej postaci. Rozwój turystyki jest bowiem często postrzegany jako najłatwiejsza droga rozwoju cywilizacyjnego, zwłaszcza kiedy posiada się unikalne dobra podarowane „przez los” i można odwoływać się do przykładów społeczności żyjących z przemysłu turystycznego. Rozważając naturę koncepcji turystyki zrównoważonej należy postawić pytania porządkujące przedmiot badania: Czym jest koncepcja turystki zrównoważonej? -ideą, normą prawną, normą moralną, wezwaniem, modelem praktyki działania? Powinniśmy także zapytać o to: Do kogo jest adresowana? - do turystów, do tubylców-mieszkańców loklaności, do organizatorów turystyki, do polityków, do świadomych obywateli świata?

Koncepcja turystyki zrównoważonej jest niewątpliwie strukturą aksjologiczną, odwołuje się do określonych, rozpoznawalnych we wspólczesnej cywilizacji wartości. Praktyki w obronie owych wartości są przedmiotem społecznego dyskursu i sporu o podłożu politycznym. Jest koncepcją nie mającą statusu normy postępowania w sensie prawnym, narzucającą formę praktyki turystycznej, za wyjątkiem obszarów chronionych, w których podstawę działania wyznaczaja regulacje prawne. W wielu kulturach szacunek dla świata przyrody i wszelkich form życia ma status normy moralnej, nakazu postępowania, W cywilizacji zachodu człowiek ma niezmiennie status bytu nadrzędnego w stosunku do świata przyrody, czego konsekwencją wydaje sie być ów brak równowagi między potrzebami świata przyrody a potrzebami człowieka. U podstaw rozwoju cywilizacji zachodu tkwi brak przyzwolenia na zawarcie kompromisu ze światem przyrody, 
ale świat zachodu nie jest skłonny również do zawarcia kompromisu społecznego przynoszącego podział zysków między członków wszystkich warstw społecznych. Stan nierówności i społecznego wykluczenia wydaje się być wpisany w podstawy indywidualistycznej cywilizacji zachodu. Współczesna cywilizacja rozwija się kosztem świata przyrody, tworzy nierówności społeczne w zakresie dystrybucji dóbr i poziomu życia, a także korzyści płynących z podejmowanych przedsięwzięć, zmienia struktury społeczne, przekształca dziedzictwo kulturowe i naturalne człowieka.

\section{Zakończenie}

Idea zrównoważenia ma zatem wyraziście polityczny aspekt wskazujący na przesłanie dzielenia się dobrami, dla którego konieczna jest zgoda na rezygnację lub nawet wyrzeczenie się częsci doznawanych przyjemności. Koncepcja turystyki zrównoważonej wydaje się mieć charakter etosu społecznego akcentującego gatunkową solidarność człowieka biorącego odpowiedzialność za tworzony przez siebie porządek społeczny i otrzymane dziedzictwo kulturowe i przyrodnicze. Isotoną kwestią wydaje się być natura owej ortodoksji zrównoważenia. Czy chcemy zlikwidować negatywny wpływ praktyki turystycznej na dziedzictwo człowieka czy tylko ograniczyć, co oznacza, że turystyka będzie jednak niszczyła nasze dziedzictwo, tylko wolniej lub w mniejszym stopniu, co nie znaczy, że odwracalnym. Koncepcja kompromisu wydaje się być przyzwoleniem na taki stan rzeczy akceptującym zgodę na mniejsze zło. Ortodoksja zrównoważenia może być odebrana jako swoisty „paternalizm turystyczny". Czy jednak mamy prawo ograniczać innych w rozwoju poprzez turystykę, nie oferując w zamian innych narzędzi, które znosiłyby podział świata na biednych i bogatych, zacofanych i rozwiniętych, chroniły przed społecznym wykluczeniem jednostek i społeczności. Konsekwencją wyhamowania rozwoju turystyki może być zmniejszanie się turystyki masowej i wzrost turystyki elitarnej, co będzie obrazem społecznych podziałów na uprzywilejowanych, wolnych i zniewolonych, czyli cofnięciem do epoki przedprzemysłowej i przemysłowej, kiedy podróżowały wyłącznie wyższe klasy społeczne.

\section{Bibliografia}

Gaworecki W., 2003, Turystyka, wyd. PWE, Warszawa

MacCannell D., 2002, Turysta. Nowa teoria klasy próżniaczej, wyd. Literackie Muza SA, Warszawa

Mazurkiewicz L., 2012, Wybrane teorie $i$ metody badawcze turystyki, wyd. AWF, Warszawa

Mosz J., 2012, Odziatywanie boomu turystycznego na zachowania mieszkańców miejscowości Małe Ciche k/Zakopanego, w: Kazimierczak M. (red.) Jakość życia w kulturowych przestrzeniach podróżowania, wyd. AWF Poznań, Poznań 2012, 332-345 Urry J., 2007, Spojrzenie turysty, wyd.PWN, Warszawa 


\section{Pragmatic and ideal aspects of sustainable tourism}

\section{Abstract}

Sustainable tourism is not considered as a form of tourism. The category "sustainable tourism" is an axiological category. The concept of "sustainable tourism" has the status of a universal idea. In the sustainable tourism model, social, economic and aesthetic needs are emphasized. They are not distributed symmetrically between groups of tourism subjects. Sustainable tourism, considered as a model for the whole tourism, must include the right to limit development and forms of tourism in the name of preserving exceptional and universal human goods. Essential for the problem of sustainable tourism seems to be the question: Is sustainable tourism adapted to the principles of modern civilization, or is it a model of action that will bring about change in the social space of the present? Keywords relating to the fair and equitable sharing of income from tourism have an overtone both social and political, in the discovery of many revolutionary ideologies. The idea of sustainable tourism indicates the link between the possibilities of meeting the universal need for travel and the need to preserve the world these travels take place. The concept of sustainable tourism seems to be a social ethos that accentuates the kind of solidarity of a man who takes responsibility for his social order and the acquired cultural and natural heritage. An important issue for the tourism development seems to be the nature of orthodoxy sustainability.

\section{Keywords}

sustainable tourism, the subject of tourism activities, tourism axiology, social sustainability 